\title{
CORPORATE BRAND EXPRESSIONS IN BUSINESS-TO-BUSINESS COMPANIES' WEBSITES: EVIDENCE FROM BRAZIL AND INDIA
}

Cláudia Simões(*), Open University Business School, Open University, Milton Keynes, MK7 6AA, UK; Tel.: +44 (0)1908654741; claudia.simoes@open.ac.uk

Jaywant Singh, Kingston Business School, Kingston University Surrey KT2 7LB, UK; Tel: +44 2084175158; j.singh@kingston.ac.uk

Marcelo G. Perin, Faculdade de Administração, Contabilidade e Economia, Pontifícia Universidade Católica do Rio Grande do Sul. Av. Ipiranga, 6681-90619-900, Porto Alegre, RS, Brazil; Tel.: +55 51 33203524; mperin@pucrs.br

(*) corresponding author

\section{Acknowledgement}

The authors are grateful to Rahul Chawdhary, John Pereira, Patricia Turmina and Agueda Vieira Martinelli for their assistance with data coding. 
Cláudia Simões ( $\mathrm{PhD}$ from University of Warwick, UK) is an Associate Professor in Marketing at the Open University Business School in the UK and is also linked to the University of Minho in Portugal. Here research interests are in strategic marketing, corporate identity, image, brand and reputation. Her work has been published in the Journal of the Academy of Marketing Science, Journal of Business Research, European Journal of Marketing, Industrial Marketing Management and others. She was, in the past, visiting scholar at Warwick Business School/UK (visiting fellow), Open University Business School/UK (senior visiting research fellow) and Scheller College of Management, Georgia Institute of Technology/USA (visiting scholar).

Jaywant Singh is Associate Professor in Marketing at Kingston Business School, Kingston University, UK. His research interests are in the areas of consumer behaviour and branding. He has published in Industrial Marketing Management, Journal of Advertising Research, Marketing Letters, Journal of Business Research, European Journal of Marketing, Journal of Business Ethics, and International Journal of Market Research, amongst others.

Marcelo Gattermann Perin (PhD from Federal University of Rio Grande do Sul, Brazil) is Professor of Marketing at the Business School of Pontifical Catholic University of Rio Grande do Sul (PUCRS), Porto Alegre-RS, Brazil. His research mainly focuses on strategic orientations, innovation management, university-industry relations, and technology transfer. His work has been published in journals such as International Marketing Review, Industrial Marketing Management, Journal of Marketing for Higher Education, Journal of Technology Management \& Innovation, Latin American Business Review, Brazilian Administration Review, among others. 


\section{Research Highlights:}

- Features representing the corporate brand in B2B companies' websites are proposed and analyzed

- Corporate brand expressions in websites should entail: values, sustainability, company demographics, heritage, and personality

- There are similarities in corporate branding activities in the two emerging economies of Brazil and India

- B2B companies with stronger corporate brand expression in websites tend to have higher financial performance 


\title{
CORPORATE BRAND EXPRESSIONS IN BUSINESS-TO-BUSINESS COMPANIES' WEBSITES: EVIDENCE FROM BRAZIL AND INDIA
}

\begin{abstract}
In the business-to-business (B2B) domain, the corporate website is an effective platform for communicating the corporate brand $(\mathrm{CB})$ features (e.g., personality, values). Despite the growing importance of websites as the primary means for corporate communication, research on the relevant dimensions for online corporate branding expression is sparse. This study examines the expressions of $\mathrm{CBs}$ on the websites of $\mathrm{B} 2 \mathrm{~B}$ companies in two emerging markets -Brazil and India. In addition, the study investigates whether the dimensions of CB have an effect on the company's financial performance. Findings highlight the following items for $\mathrm{CB}$ expressions in the website: $\mathrm{CB}$ values; $\mathrm{CB}$ personality; sustainability in the $\mathrm{CB}$; $\mathrm{CB}$ heritage, and company demographics. There are similarities in the $\mathrm{CB}$ expressions in India and Brazil. In addition, the findings show that higher levels of strength in the expression of the $\mathrm{CB}$ in the website lead to higher levels of financial performance. Managerial recommendations and avenues for future research are presented.
\end{abstract}

KEYWORDS: corporate branding, financial performance, B2B, Brazil, India, website 


\section{CORPORATE BRAND EXPRESSIONS IN BUSINESS-TO-BUSINESS COMPANIES' WEBSITES: EVIDENCE FROM BRAZILIAN AND INDIAN COMPANIES}

\section{Introduction}

In the current competitive business environment, companies operating in B2B contexts look for sources of competitive advantage grounded at the corporate level. Creating unique forms of presenting the company and managing stakeholder's perceptions of a corporation provide an important basis for sustainable competitive advantage. Developing a strong corporate brand $(\mathrm{CB})$ is a possible instrument for corporate presentation as it entails visual and behavioral expressions of the organization's uniqueness (Knox \& Bickerton, 2003). Companies in $\mathrm{B} 2 \mathrm{~B}$ contexts are concerned with managing $\mathrm{CBs}$ as they have key business benefits. For example, perceptions related to the supplier company (Aspara \& Tikkanen, 2008a) and supplier reputation (Roberts \& Merrilees, 2007) affect the business customer's purchasing decisions; the $\mathrm{CB}$ allows organizations to differentiate themselves in the marketplace and impacts on business performance (Kay, 2006; Herbst \& Merz, 2011; Glynn, 2010). That is, a strong CB brings long-term benefits to the company (Inskip, 2004). Ultimately, the CB is a key strategic instrument and asset through which the organization can differentiate itself from competitors and can articulate the purpose of the organization and its business model.

In order to create uniqueness and positioning for multiple stakeholders, B2B companies increasingly enunciate features (dimensions) of $\mathrm{CB}$ as, for example, company values, $\mathrm{CB}$ personality, the company's activities towards sustainability, and company heritage. Such features strengthen and consolidate the $\mathrm{CB}$, and in turn may influence the performance and profitability of the company. Thus, well-articulated features may prove vital for the success and endurance of the CB (Herbst \& Merz, 2011). Although there is an increasing interest in the study of corporate branding in B2B contexts (e.g., Aspara \& Tikkannen, 2008a; 2008b; van Riel, de Mortanges, \& Streukens, 2005; Herbst \& Merz, 2011; Webster \& Keller, 2004) and its relevance is well-established, there is still a paucity of research addressing the combination of features of CBs used to convey and present the CB. In particular, the expression of the $\mathrm{CB}$ in $\mathrm{B} 2 \mathrm{~B}$ contexts in different platforms, such as the internet, and its impact in business performance is not fully understood, with little related research conducted 
in emerging economies. Hence, the motivation for this study is grounded in three key aspects: (i) the need for understanding the representations of $\mathrm{CB}$ features in a B2B context in different platforms, such as, the internet; (ii) the need for establishing a clear connection between $\mathrm{CB}$ expressions and financial performance; and (iii) the need for insights into CB management in companies in emerging economies.

$\mathrm{CB}$ development and management is a challenging and complex endeavor in current dynamic business contexts and increasingly sophisticated media. A review of studies on corporate branding reveals that research investigating $\mathrm{CB}$ features in $\mathrm{B} 2 \mathrm{~B}$ settings tends to focus on specific aspects (e.g., van Riel et al., 2005; Beverland, Napoli, \& Lindgreen, 2007; Herbst \& Merz, 2011) and features of CB, such as, values (Lynch \& Chernatony 2004). Yet these do not examine the combination of features needed to express the $\mathrm{CB}$ in an on-line setting. Technology and the internet have transformed the ways communication and interactions occur (Keller 2009). To convey and articulate the CB, companies attempt stronger online presence (Michaelidou, Siamagka \& Christodoulides, 2011). The company's website is frequently the first contact that stakeholders have with the company, being a relevant instrument for creating a consistent company presentation to stakeholders. Often companies use an online presence to shape their corporate brands and build relationships with audiences (Booth \& Matic, 2011). Given that an increasing number of B2B companies tends to, or aspires to, operate at a global level (Lindgreen et al., 2010), the company website is a vehicle of corporate presentation showing its commitments to the various publics (Esrock \& Leichty, 2000). It becomes a particularly relevant reference to convey the CB. However, little is known about the way the CB is expressed in the company's website.

Brands are believed to leverage business performance. The underlying idea is that brands drive business performance since they affect market perceptions of the company's offerings (e.g., quality) and generate loyal customers willing to pay a premium price for a trusted brand. Ultimately strong brands have higher sales volume, profits and shareholder value (Ellwood, 2002; Keller, 2008; Doyle, 2000). Although the rationale for the financial impact of brands is well-established, there is still a paucity of research that empirically tests the $\mathrm{CB}$ features that should be emphasized for attaining consistent managerial goals, such as, creating a strong CB image, and achieving higher levels of business performance. In addition, the prevailing reference for research in $\mathrm{CB}$ is still with an emphasis in the developed economies context. The generalizability of the practices may not always occur, in particular in the context of 
emerging economies (Burgess \& Steenkamp, 2006). Consequently, there have been calls for research in different contexts, in particular in emerging economies (e.g., Sheth, 2011; Wiersema, 2013). Emerging economies become 'natural laboratories' for research and for the development of contingent theories. Consequently, they support the assessment of the robustness of (marketing) knowledge among distinct backgrounds (Burgess and Steenkamp, 2006). Given the high number of B2B companies originating in emerging markets (Kumar and Steenkamp, 2013), it is vital to understand their expressions of CBs on the companies' websites and verify the impact in business performance.

This paper focuses on the analysis of the features of $\mathrm{CB}$ that are represented in $\mathrm{B} 2 \mathrm{~B}$ companies' websites in two key emerging economies - Brazil and India. The contribution of this research is threefold. First, studies in the B2B context do not tend to systematize the features that should be used to represent the $\mathrm{CB}$ and, as a consequence, overlook representations of $\mathrm{CB}$ in websites. By systematically analyzing $\mathrm{CB}$ representations in websites, we aim to bring insights into CB expressions in web platforms. Second, we address the implications of CB expressions for the company's financial performance. Third, considering that little is known about $\mathrm{CB}$ in different environments, we bring insights into $\mathrm{CB}$ practices in the context of two prominent emerging economies.

\subsection{The emerging markets of India and Brazil}

BRIC $^{1}$ (Brazil, Russia, India, and China) countries have been having a relevant role in the world economy over the last decade. These countries are increasingly seen as established markets for investment (BDO, 2012). They have a large manufacturing and service base capacity, producing relevant economic exchanges among themselves and world-wide (Biggeman \& Fam, 2011). A great amount of these exchanges occur globally in B2B settings.

In this study we focus on India and Brazil, which are two prominent members of the BRIC group and amongst the top five international investment destinations (BDO, 2012). Evidence from the two countries shows strong recent growth in the industrial sector. Forecasts suggest that the two economies will continue to grow. According to a study by Goldman Sachs, by the year 2050, India and Brazil are going to be world's third and fourth economies after the US

\footnotetext{
${ }^{1}$ The Acronym has been extended to BRICS including South Africa.
} 
and China (Wilson \& Purushottam, 2003). The recent formation of the BRICS Bank (2014) (formally known as the New Development Bank) further consolidates the two countries' position in terms of future prospect of industrial growth. A number of B2B companies in the two countries have international or global operations, and a growing number are expanding internationally. As the B2B companies in these countries expand, they are investing in branding activities, or are becoming aware of the need for branding and corporate identity creation. Therefore, the countries provide apposite settings for conducting the present study.

\section{The Brazilian context}

The Brazilian economy has grown over the past decade. In 2011 the economy grew at the rate of 7.5\% (MDICE, 2011). For the period 2010-2015, the estimated average growth rate of the industrial GDP for the Brazilian economy is $8.5 \%$ (CNI, 2010). There is an overall optimism on the increasing internationalization of the Brazilian companies. Such internationalization has been facilitated by the international alliances (Brazil is part of the Mercosur) and by increasing recognition of the BRIC countries in the international business arena (BDO, 2014). A substantial number of businesses operate in the B2B and industrial markets. Increasingly, companies including those operating in $\mathrm{B} 2 \mathrm{~B}$ markets, maintain a web presence.

\section{The Indian context}

Following economic liberalization, the Indian economy has shown sustained growth over the past decade, with an average GDP growth rate of 7.6\% during 2004-13 (Planning Commission, 2014). Much of this growth is fuelled by a healthy industrial growth rate that averaged at $7 \%$ during the same period. The IMF has made a positive forecast for the economic indicators in India, with industrial growth set to keep its momentum in coming years (Kapur \& Mohan, 2014). English is a widely spoken language and the country has become a center for many global companies (Gupta \& Shapiro, 2013). The rapid growth of the industrial sector is characterized by increasing internationalization of the companies, especially in the B2B sector. Almost all B2B companies listed on the stock exchange, large or small-sized, maintain a web presence. 


\section{Background}

The notion of a $\mathrm{CB}$ reflects an understanding that the brand concept can be applied at the corporate level (Aaker, 1996). As opposed to the product brand that relates to what the brand does and represents, the $\mathrm{CB}$ entails what the brand does but also who the brand is (Keller \& Richey, 2006). The CB needs to be considered and managed as a strategic asset (Webster \& Keller 2004). As Ind (1997) explains, "a corporate brand is more than just the outward manifestation of an organization - its name, logo, visual presentation. Rather it is the core of values that defines it' (p. 13). Such an overarching view of the CB is echoed in Knox and Bickerton's (2003) definition of CB: "the visual, verbal and behavioral expression of an organization's unique business model" (p. 1013).

This idea of behavioral expression and uniqueness of the organizations may be linked to the notion of corporate identity. Corporate identity refers to the uniqueness and character of the company (Simões, Dibb \& Fisk, 2005). In this regard, Abratt \& Kleyn (2011: 1053) consider the $\mathrm{CB}$ as “...expressions and images of an organization's identity” being instrumental in conveying the organization's identity. The CB and its identity ought to be consistent with the corporate identity reflecting the organization's being and core values. In fact, the corporate brand tends to be based in, and incorporate relevant features of the corporate identity, especially in its genesis (Balmer, 2012). As Balmer (2001) explains, "A corporate brand involves the conscious decision by senior management to distil and make known the attributes of the organization's identity in the form of a clearly defined branding proposition" (p. 281). Hence, it seems that features of corporate identity will be a part of the CB.

The notion of brand identity may also assist the understanding of effective brand management and establishment of brand features. Traditionally, the branding literature portrays brand identity as the differentiating and core idea of the brand (Aaker, 1996; Kapferer, 2008; Coleman, de Chernatony \& Christodoulides, 2011). The brand is the cue to an offer and should act as "a long lasting and stable reference" (Kapferer, 2008, p. 37). Yet, brand identity is expected to evolve where "(...) core values maintain consistency over time while other dimensions vary, when needed, to adjust to the environmental context" (da Silveira, Lages \& Simões, 2013: 33). When presenting the brand identity, managers ought to account for the brand vision and values, brand differentiators, brand signs or symbols that make it recognizable (Kapferer, 2008). Consequently, there are levels of brand identity entailing 
distinct groups of brand elements namely, the product, organisation, personality and symbols (Aaker, 1996; Aaker \& Joachimsthaler, 2002).

\subsection{Expressing Features of CB in websites}

Creating and managing a $\mathrm{CB}$ has a number of challenges. For example, the entity in corporate branding has a high level of intangibility, complexity and (social) responsibility leading to problems in building a coherent brand (Knox \& Bickerton, 2003). In particular, the development of a $\mathrm{CB}$ for companies operating in $\mathrm{B} 2 \mathrm{~B}$ settings needs to take into account the role that $\mathrm{CB}$ may have for the company and the dynamics of B2B markets (e.g., few buyers; great volume purchases, etc.). As offers tend to converge in terms of price, quality and other features, intangible differentiation assumes particular importance. Such differentiation tends to rely on aspects, such as, reputation, innovation, personality, and relevance that can be assimilated by the over-arching brand (Lindgreen, Beverland, \& Farrelly, 2010). The CB, thus, differentiates (Inskip, 2004) and contributes to build an overall corporate image and firm qualification image that are relevant in business purchasing decisions (Blombäck \& Axelsson, 2007).

CB has a multiple stakeholders' perspective (Gylling \& Lindberg-Repo, 2006) and needs to be conveyed through comprehensive and integrated channels of communication across all platforms (Balmer, 2012). Corporate websites, as means of corporate communication, are powerful tools for promoting corporate identities (Topalian, 2003), and ultimately presenting CB features. As Esrock and Leichty (2000: 329) state, “... a corporate Web site becomes an iconic representation of the corporation. (...) Web sites should be viewed as an intentional act of communication that signifies an organization in its multiple facets to its multiple publics." Websites may, thus, become a platform to express the brand character (Keller, 2009).

CB features are expected to be highlighted in accordance to the platform used to express the brand. Certain CB features are part of the corporate identity and/or brand identity. Building on previous research (Hatch \& Schultz, 2003; Aaker, 2004; Kapferer, 2008; Keller, 2009), we propose that the following features are of particular relevance to convey the $\mathrm{CB}$ in the company website: $\mathrm{CB}$ values; $\mathrm{CB}$ personality; Sustainability in the $\mathrm{CB}$; $\mathrm{CB}$ heritage; Company leadership (company founder and/or top management); Company demographics. 
We now present the CB features and the rationale for their inclusion in companies' websites in more detail.

\section{$C B$ values}

The CB values feature attempts to reflect the essence and purpose of the company. Overall, it captures the unique and differentiating factors of the brand (Aaker \& Joachimsthaler, 2002; Lassen, Kund \& Gioia, 2008). This feature is linked to the corporate strategy (Aspara \& Tikkanen, 2008b), revealing the company's priorities (Aaker, 2004). Hatch \& Schultz (2003: 1047) refer to the strategic vision of the $\mathrm{CB}$ as capturing the "central idea behind the company that embodies and expresses top management's aspiration for what the company will achieve in the future." Hence, in order to manage the CB it is important to comprehend at the corporate level the values and the guiding philosophy and identity of the company. As Gylling \& Lindberg-Repo (2006: 262) explain, "[i]n the internal brand-building process, the core values link mission, vision and organizational values".

The dissemination of mission and values has been established as a feature of the management of corporate identity (Simões, Dibb \& Fisk, 2005). The company's core values and beliefs are an organization's essential guideline on what is important to the business, and its role in the society. The company's purpose results from its central values and beliefs. The company's mission is, thus, the purposeful goal that challenges the organization to move forward and becomes a tangible element of the company's image (Collins \& Porras, 1991). Previous studies showed the presence of vision/mission statements in websites (Uzunoglu \& Kip, 2013), being a frequently used tool for communicating corporate identities (Pollach 2005). We propose that as part of the $\mathrm{CB}$ expression, companies in $\mathrm{B} 2 \mathrm{~B}$ markets present their mission and values in their websites.

\section{CB Personality}

Brands have a character and convey certain personality traits to customers and other stakeholders. The idea of brand personality brings in human characteristics to brands (Torelli et al., 2012), referring to 'the set of human characteristics associated with a brand' (Aaker, 1997, p. 347). Various authors consider brand personality as a dimension of brand identity 
(e.g., Aaker \& Joachimsthaler, 2002). The notion of personality applied to CB reflects "the values, words and actions of employees, individually and collectively...should reflect the corporate values held by the organisation" (Keller \& Richey, 2006: 75). As B2B decision making increasingly entails emotional and functional aspects (Davis, Golicic, \& Marquardt, 2007; Lindgreen et al., 2010), CB personality and its expression has particular relevance (Coleman et al., 2011).

The literature does not present a clear measurement for the CB personality. Nonetheless, previous studies give relevant insights. For example, Keller and Richey (2006) suggest a company's personality should be based in three traits: passionate and compassionate in addressing the market and stakeholders; creative and disciplined in its approach to markets; and, agile and collaborative in addressing market dynamics and changes. Coleman et al. (2011) consider brand personality as part of the service brand identity construct and measured by the "strength, favorability and uniqueness of the brand personality association" (p. 1066).

Previous studies have addressed the CB personality dimensions in companies' websites with the underlying idea that personality attributes lead to CB differentiation (Ingenhoff \& Fuhrer, 2010; Abdullah, Nordin, \& Aziz 2013). For example, Okazaki (2006) found the following online personality traits in American MNCs websites: sophistication, excitement, affection, popularity, and competence. Opoku, Bendixen and Pitt (2007) covered CB personality dimensions in SMEs considering the following traits: sincerity; excitement; competence; sophistication; and, ruggedness (based on Aaker, 1997). In our study we propose that CB personality needs to be expressed in the company's website as a way to set the character and tone for the brand.

\section{Sustainability in the $C B$}

The sustainability feature brings the intended impact of the company in the community and in the overall well-being. Initial references to such perspective in branding were linked to the idea of $\mathrm{CB}$ citizenship. $\mathrm{CB}$ citizenship refers to the concerns that people within the organization have for the environment and the community in general. The idea is that such concerns should be reflected in the CB (Aaker, 2004). This notion is also akin to the concept of corporate social responsibility (CSR). CSR “(...) has most generally been used to refer to organisational behaviour or outcomes that are consistent or congruent with societal norms, 
values and expectations" (Lerner \& Fryxell, 1994: 60). Recent work refers to the notion of sustainability as over-arching in nature (Kumar \& Christodoulopoulou, 2014). Corporate sustainability may be understood as a business approach to company's activities having a voluntary and pro-active inclusion of social and environmental concerns in business operations and in interactions with all the organisation's stakeholders in the long-run (Gupta and Kumar, 2013). Such idea takes into account a balanced view of the following three dimensions: social, environmental and economic (Gupta \& Kumar, 2013; Kumar \& Christodoulopoulou, 2014).

A relevant direction for $\mathrm{B} 2 \mathrm{~B}$ companies is to consider issues of social responsibility in their brand management (Kotler \& Pfoertsch, 2007). Sustainability and marketing ought to be integrated, being the brand instrumental in supporting and conveying sustainability practices (Gupta \& Kumar, 2013; Kumar \& Christodoulopoulou, 2014). Gupta, Czinkota \& Melewar (2013) advocate embedding sustainability into brand knowledge and brand value for creating differentiation for the brand in a competitive market. Previous research refers to a more or less prominent social responsibility (Esrock and Leichty, 2000) or sustainability (Adams \& Frost, 2006) references in companies' websites. This discussion points out that communicating the company's sustainability approaches in the website can enhance the strength of the corporate brand. We extend this idea to the online communication of sustainability wherein as a $\mathrm{CB}$ dimension it captures the expressions and embedding of sustainable practices being undertaken by the company.

\section{CB Heritage}

In general terms, heritage is connected to inheritance, that is, refers to the transference of a legacy across generations (Nuryanti, 1996). Brown, Kozinets \& Sherry (2003) refer to brand heritage " ... as using marketing-mix variables that invoke the history of a particular brand, including all its personal and cultural associations" (p. 20). Transposing the above notion to $\mathrm{CBs}$, the term brand heritage captures the history of the $\mathrm{CB}$ since its creation. The underlying rationale is that the history (and evolution) of the company is a relevant corporate association (Persson, 2010). The company's history helps shaping the brand throughout time (Aaker, 2004) conveying stability and familiarity (Hakala, Lätti \& Sandberg, 2011). 
The idea of brand history and heritage is well covered in the consumer literature (e.g., Brown et al., 2003). Overall, studies show the role that brand heritage and history may have in the protection and continuity of the brand (e.g., Simms \& Trott, 2006). When analyzing in particular the $\mathrm{CB}$, stories about the beginning of the company, its evolution and its founders generate relevant associations to the CB (Aaker, 2004) constituting a relevant way to generate credibility and trust. According to Keller (2009: 147) "websites can (...) convey rich accounts of history, heritage and experiences". For example, presenting corporate histories/business descriptions in the website may be a relevant aspect to convey the brand to investors (Esrock \& Leichty, 2000). Hence, in today's dynamic and competitive environment to market a company's website is an important platform for conveying the brand heritage and history as part of the CB features.

\section{Company leadership: founder and/or top management}

The company leadership feature of the $\mathrm{CB}$ attempts to capture the influence that the founder and/or top management may have in the definition and portrayal of the brand. According to Kapferer (2008), the brand creator's identity is closely connected to the brand identity (e.g., Richard Branson with Virgin). The company leadership is an important corporate association (Persson, 2010). Such associations are nurtured through communication of the founder's vision and charisma. Information about the origins of the company, and the role of the visionary founder is communicated with the purpose of creating an appealing persona of the company and generate an emotional bond between the company and the stakeholders (e.g., Lynch \& de Chernatony, 2004; Carlson, Suter \& Brown, 2008). As suggested by Aaker (2004), the people of an organization provide the basis for the corporate brand image. In particular, the individuals at the top level speak for and represent the corporation. Abratt and Kleyn (2012) refer that a strong leadership leads to corporate reputation and instils confidence amongst the stakeholders. The company leadership, thus, communicates an important dimension of the CB (Vallaster \& de Chernatony, 2006). Portraying such features in the company's website strengthens the relevance and reliability of the CB. 


\section{Company demographics}

Company demographics entail the physical aspects that allow describing the company and creating relevant knowledge about the company. For example, size and type of industry are relevant corporate associations (Persson, 2010). Other related information about the company's total employee strength, physical assets, location, and the number of subsidiaries, also play an important role towards creating an association towards the company and defining its profile. Such content brings in a more tangible dimension to the brand, being part of its expression and image. In particular, it allows associations as to the strength of the brand and its potential. The presentation of the $\mathrm{CB}$ in the company's website should, thus, entail demographic information portrayed as a brand feature.

\subsection{CB vs. performance}

Business performance essentially relates to the measurement of the company's success. In this paper we focus on the relationship between expressions of CBs and financial measures (e.g., sales, revenue). There has been a long debate in the branding literature frequently referring to higher performance outcomes to be attained by companies developing an active brand management (Munoz \& Kumar 2004). Generally speaking, brands elicit favourable responses from markets and therefore enhance revenue, lower costs and raise profit levels (Ellwood, 2002; Keller, 2008). Strong brands contribute to generate shareholder value. As Doyle (2000: 229) states, "[b]rands are resources that contribute to the firm's capabilities in running its core business processes of managing its product development, supply chain and customer relationships. The effectiveness with which it runs these processes determines its ability to create value for customers and shareholders."

While the financial benefits of strong brands are well addressed in the literature and the rationale is clear, empirical work sustaining such argument is still scarce. In particular there does not seem to be substantial empirical research addressing the relationship between $\mathrm{CB}$ management and financial performance measures. Exceptions may be found in the studies of Rao et al. (2004) that established a higher impact of CB strategies in Tobin's q ratio ${ }^{2}$, when

\footnotetext{
${ }^{2}$ Tobin's q ratio refers to "the ratio of the market value of the firm to the replacement cost of the firm's assets. It is a forward looking measure providing market-based views of investor expectation of the firm's future profit potential" (Rao et al., 2004: 129).
} 
compared with mixed branding or house of brands strategies; and, Kotler and Pfoertsch (2007) who found evidence that B2B brand strength impacts on financial performance. Related constructs are also shown to have an effect on business performance. Corporate identity programmes may have an instrumental role in obtaining a high price/earnings ratio (Gray \& Smeltzer, 1987). Fombrun and Shanley (1990) view reputation as the image attached to the name of a corporation and demonstrated a link between historical performance and company reputation. In a similar vein, Eberl and Schwaiger (2005) established a positive relationship between corporate reputation dimensions and financial performance.

In this study we attempt to explore the relationship between the strength of expression of $\mathrm{CB}$ features in websites and financial performance measures. The underlying rationale is that companies that present a clear and strong expression of their $\mathrm{CBs}$ have a more active $\mathrm{CB}$ management and, therefore, will tend to present a higher level of financial performance.

\section{Method}

We analyzed Brazilian and Indian B2B companies' websites, focusing on the pages containing corporate information and/or information about the parent company. That is, we focused on over-arching information about the company as a whole, rather than on specific information, such as, products lines or services. The data collection and analysis was developed in 2 stages: pilot and main study. The pilot study aimed at developing and refining the CB features' description, and testing the coding procedure. The main study entailed the test of the CB features and their relationship with performance.

\subsection{Pilot study: developing and testing the coding procedure}

The following CB features were considered: CB values, CB personality, Sustainability in the $\mathrm{CB}$, Company founder and/or top management, and Company demographics. Considering that the objective was to capture the relative strength of the features across the websites, a Likert scale was used assessing the level of presence of the CB feature in the website.

An initial coding scheme was applied to the Brazilian and Indian test samples of 100 companies each. For this procedure, the companies were selected from national publications entailing the lists of 1000 biggest Brazilian and Indian companies that operated in B2B 
markets. Two independent researchers - one Brazilian and one Indian - coded a total of 100 cases for each country, respectively. The coders were instructed by a research team member and had close supervision while coding the initial cases. The Brazilian coder was then asked to independently code the Indian sample, as all Indian websites were in English. The reverse procedure was not possible as the Indian coder did not know the Portuguese language, and most of the Brazilian websites were either in Portuguese or had significantly less detailed information in English. The intercoder reliability (i.e., commonality in coding) was $80 \%$ which is above the acceptable benchmark (Perreault \& Leigh, 1989).

The pilot study allowed detecting inconsistencies in the coding procedure. Based on this stage a revised and refined version of the conceptual and operational coding procedures was developed. Table 1 presents the final description of the $\mathrm{CB}$ features, later included in the main analysis. The 5-point Likert assessment scale description was as follows:

1) The feature is not present in the website - the feature is absent from the webpage;

2) Low presence of the feature in the website;

3) Medium presence of the feature in the website - the feature is present in the webpage, yet it is only vaguely/medially addressed;

4) Strong presence of the feature in the website - the feature is solidly/clearly present/displayed in the webpage;

5) Very strong presence of the feature in the website - the feature is prominently present and addressed in the website, and is featured in an unequivocal and highlighted manner.

In order to address the individual-specific subjectivity involved in assigning assessment scores, the research team developed a common protocol about what constitutes 'high' or a 'low' score. The consistency of scoring patterns was monitored throughout the process, by reviewing the scores of the first fifteen companies, before proceeding to the next group of companies. This precaution helped in generating consistent and reliable sets of scores for the $\mathrm{CB}$ dimensions from both countries.

Place Table 1 Here 


\subsection{Main study}

The main study incorporated the final description of the CB features and the assessment scale presented in the previous section. The study further included performance measures. We used secondary data to extract performance measures based on the stock index data from Bloomberg (www.bloomberg.com). The Bloomberg data contains three main performance indicators:

1) Market capitalization - total dollar market value of all the company's outstanding shares at period end date;

2) Net revenue - the sum of Interest Income, Trading Account Profits (Losses), Investment Income (Losses), Commissions and Fees Earned, and Other Operating Income, minus Interest Expense;

3) Total assets - the sum of cash and bank balances, government funds sold and resale agreements, investments for Trade and Sale, Net loans, Investments held to maturity, Net fixed assets, Other assets, Customers' Acceptances and Liabilities.

\section{Website selection and sample profile}

The companies selected for the main study operate in the B2B context in Brazil and India and were all listed in the Bloomberg Stock Market Index. The Index contains companies trading in the stock market in the two countries including their performance measures of Market Capitalization, Net Revenue, and Total Assets. The companies presented different levels of performance.

Altogether 158 Indian and 158 Brazilian B2B companies from twelve industries in each country were included in the analysis. A proportional number of companies representing each industry was selected and randomized. The samples kept the population distribution in terms of industries. Because the selection of the cases was randomized, any potential bias due to different levels of performance of the companies was mitigated. Table 2 shows the industries and the number of companies' websites in the sample.

Place Table 2 Here 


\section{Coding procedure and data analysis}

Considering the coding procedure developed during the pilot study, the research team members tested together the coding of 5 cases in each country's sample. Next, the two independent coders (one Brazilian and one Indian), analyzed the respective datasets. Particular attention was given to the training instructions transmitted to the coders as learned during the pilot study. In order to assess the inter-observer reliability, a test of 15 cases was conducted in the two samples and coded by one member of the research team. The intercoder reliability in this set of cases was highly convergent. A further round of discussion between the research team and the coders was conducted in order to check and reconcile any minor inconsistencies. An overall agreement with the attributed codes was reached.

Data analysis involved descriptive statistics, Exploratory Factor Analysis (EFA), confirmatory factor analysis (CFA), and Structural Equation Modeling (SEM). SPSS and AMOS software were used for the data analysis.

\section{Findings}

\subsection{Measurement validation}

Our key objective was to measure CB expressions and features in companies' websites. We empirically examined the $\mathrm{CB}$ features: $\mathrm{CB}$ values; $\mathrm{CB}$ personality; sustainability in the $\mathrm{CB}$; CB heritage; company leadership (company founder and/or top management); company demographics. Due to the novelty of the measurements, we followed various steps to validate our data. First we conducted EFA to test the grouping of the data using varimax rotation and principal components analysis. Results were computed to each country's sample separately. The Indian sample produced one single factor with all features presenting high factor loadings ranging from 0.692 to 0.859 . The Brazilian sample yielded one dimension, yet the feature 'Company leadership: founder and/or top management' presented a low level of factorial loading (0.283) and communality (0.080). All other features presented high factor loadings ranging from 0.69 to 0.88 . Such finding may be explained by the fact that Brazilian managers do not consider necessary to provide information about the company founder or top management. Hence, it is uncommon to present such type of information in the company's website. In order to proceed with the analysis in both samples, the feature 'Company leadership: founder and/or top management' was dropped. All final CB features presented 
high significant correlations amongst themselves in both samples. The lowest correlation value in the Brazilian sample was $0.311(\mathrm{p}<0.01)$, whereas in the Indian sample was 0.340 $(\mathrm{p}<0.01)$.

We further assessed the metric invariance of the CB measure across both countries with SEM. We followed procedures recommended by Byrne (2004) to test multigroup invariance. First we evaluated the difference in the $\chi^{2}$ by comparing the model with free parameters in each group against a model with constrained equal factor loadings between groups. Second, we tested the invariance of factor covariances by constraining the model to vary its covariances equally between subsamples. The results confirmed measurement invariance between both countries. Such finding allows conducting the analysis in a merged database with both the Brazilian and Indian sub-samples, as well as, individually comparing the results across both countries.

We conducted CFA on the merged sample (to assess measurement reliability regarding the $\mathrm{CB}$ features measurement and performance indicators). Due to the financial nature of the performance measures, we applied z-score transformation to reduce potential multicollinearity (e.g., Cohen \& Cohen, 1983). The model's fit indices were good. Convergent validity was supported by highly significant $(\mathrm{p}<0.001)$ factor loadings for each feature in the corresponding construct (Table 3). Internal consistency and convergent validity were further evidenced by the acceptable levels of Cronbach alpha values, composite reliability (CR) and the average variance extracted (AVE) scores. To assess discriminant validity, we contrasted the squared correlation of each factor pair with the variance extracted from each factor (Fornell \& Larcker 1981). In each case, the average variance extracted exceeded the squared correlation, supporting discriminant validity. Table 4 summarizes these results. Overall we found a good quality level for our measurements.

Place Table 3 Here

Place Table 4 Here 


\section{2. $C B$ features}

The analysis of the CB features in both samples suggested distinct levels of strength in the various features. The $t$-test revealed a significant $(\mathrm{p}<0.01)$ difference in all CB features means between both countries. Such result conveys that there is a distinct approach to the level of presence of certain $\mathrm{CB}$ features in the companies' websites. Overall, the strength of the presence of the $\mathrm{CB}$ features in the websites tended to be stronger in Brazil than in India.

Table 5 presents the mean and standard deviation for each CB feature in the Brazilian and in the Indian samples, separately. In both countries, the two most pervasive features in the websites are the 'CB personality' and 'company demographics' (see Table 3). In Brazil the least relevant $\mathrm{CB}$ feature represented in the websites is the ' $\mathrm{CB}$ values', whereas in India is 'Sustainability in the CB'.

Place Table 5 Here

It should be highlighted that although the results suggested a difference on the magnitude of the $\mathrm{CB}$ features, the composition of the dimensions is the same in the two sub-samples. Such result suggests an existing similarity in the scope of online $\mathrm{CB}$ expressions for companies operating in the B2B context.

\subsection{CB features vs. performance}

To assess the impact of CB on performance we used SEM with the maximum likelihood (ML) estimation method. The applied model is depicted in Figure 1. The company industry was used in the analysis to control alternative explanations for any observed effects. The merged samples model presented a good fit $\left(\chi^{2}=19, \mathrm{df}=26, \chi^{2} / \mathrm{df}=2.643, \mathrm{RMSEA}=.072\right.$, $\mathrm{SRMR}=.068, \mathrm{TLI}=.942, \mathrm{CFI}=.958$ ). The direct impact of $\mathrm{CB}$ on performance was positive and significant $(\beta=.181 ; t$-value $=2.948 ; \mathrm{p}<.01)$.

We also assessed the impact of CB on performance in each sub-sample and for any potential differences between the two countries. We compared a model in which the path coefficient between $\mathrm{CB}$ and performance was constrained to be equal in the two sub-samples with a 
model in which the same path was unrestrained. The models were significantly different $\left(\Delta \chi^{2}(1)=17.351 ; \mathrm{p}<.01\right)$. Although the effect of $\mathrm{CB}$ on performance was significant in both samples, the effect of $\mathrm{CB}$ on performance was significantly stronger in the Indian sample $(\beta=.417 ; t$-value=4.654; $\mathrm{p}<.01)$, when compared to the Brazilian sample $(\beta=.212 ; t$ value=2.508; $\mathrm{p}<.05)$.

\section{Place Figure 1 Here}

The fact that the impact of CB features on performance is higher in India, may be connected to the way $\mathrm{CBs}$ are represented in the two countries and the geographical scope of their business interactions. The Indian companies tend to have their webpages in English, suggesting a global reach. The Brazilian companies tend to have their pages in Portuguese conveying a more regional interaction with, for example, the Mercosur countries. Consequently, because the website would be particularly relevant for a wider reach of business partners, the way the $\mathrm{CB}$ is portrayed seems to have a higher direct effect on the financial performance.

We further analyzed the correlation between the individual $\mathrm{CB}$ features and the individual measures of performance (Table 6). In both sub-samples, the features 'Corporate sustainability in the $\mathrm{CB}$ ' and 'Personality of the CB' show a significant correlation across all performance dimensions. In the Indian sample, 'company demographics' also has an expressive correlation with all the performance measures. Noticeably, the feature 'CB values' does not show a significant correlation with any of the performance measures in both countries, and 'CB Heritage' does not show a significant correlation with market capitalization in both sub-samples.

Concerning the relationship between the individual $\mathrm{CB}$ features and overall performance, there is a significant correlation in both sub-samples between the features 'Sustainability in the CB', 'Heritage of the CB', 'Personality of the CB' and the overall performance measure. In the Indian sample the feature 'company demographics' also has a significant correlation with the overall performance measure. It should be noted, however, that although some of the CB features do not have a significant correlation with performance, all CB features are highly correlated amongst themselves in both sub-samples (see Appendix). 
Place Table 6 Here

\section{Conclusions and implications}

This study constitutes an initial attempt to gain insights into the expressions of $\mathrm{CB}$ in the companies' websites operating in a B2B setting. The study further addresses the impact of the strength of those expressions in the companies' financial performance. The context underlying this research entails two emerging economies: Brazil and India. Combining these three angles, the study allows drawing relevant contributions.

Concerning the implications to the CB literature, one of the contributions of the study regards the specification of relevant elements that should be used to express the $\mathrm{CB}$ in an-online setting. In particular, it was attempted to capture those CB traits that allow establishing the strength of the expression of the $\mathrm{CB}$ in the website. The study proposes that the following features should be considered: $\mathrm{CB}$ values; $\mathrm{CB}$ personality; sustainability in the $\mathrm{CB}$; $\mathrm{CB}$ heritage, and company demographics. Building on the branding and brand identity literatures (e.g., Aaker, 2004; Kapferer, 2008), the proposed combination of traits expands the understanding of $\mathrm{CB}$ management by giving insights into the scope of the expression of the $\mathrm{CB}$ in on-line platforms in $\mathrm{B} 2 \mathrm{~B}$ settings. The consideration the $\mathrm{CB}$ expression with an on-line perspective has been so far overlooked (Keller, 2009), especially in the B2B and the emerging market contexts.

An additional contribution stemming from this study concerns the expansion of marketing knowledge by testing theories in different settings and backgrounds, such as the context of emerging economies (Burgess and Steenkamp, 2006). This study identified the features of CB expressions in companies' websites in two important emerging economies and examined companies that operate in the $\mathrm{B} 2 \mathrm{~B}$ context. The study suggested the stability of the dimensions when applied to companies from two different emerging countries, supporting the idea that there may be commonalities in the way businesses happen in emerging economies (Sheth, 2011). The fact that Brazilian and Indian companies are relevant business partners may suggest that this communality in brand expressions is a bridge for interaction and 
understanding of business partners. Moreover, the study suggests that in emerging economies, companies that operate in $\mathrm{B} 2 \mathrm{~B}$ settings are concerned with developing forms of on-line expression of their CBs. Such forms tend to include similar features to the ones derived from studies conducted in the western economies. Hence, it seems that there are pockets of companies in emerging economies that show similar CB management practices to the ones in western economies. This aspect should take into account the fact that the companies in the study were listed in the stock market and, therefore, had a certain level of financial trade and size. There is also a great heterogeneity of industries in emerging markets, presenting a large number of owner-managed small enterprises as well as large-scale domestic companies (Sheth, 2011). Such heterogeneity may explain the fact that some companies in those markets have a similar nature of corporate branding practices to those companies located in western economies.

The study further showed a positive impact of the level of CB on-line expressions on business performance. There are abundant references in the literature on the benefits of brands, including the expected positive impact of strong brands on financial performance (e.g., Doyle, 2000; Keller, 2008). Such references are, however, rarely verified with empirical data. In this study, we specified items for the online expression of CBs, and tested their impact on financial performance. To the endeavor we employed objective performance indicators, thus avoiding the biases of subjective measures. In general terms, the study established that higher levels of strength in the expression of the $\mathrm{CB}$ in the website lead to higher levels of financial performance. Hence, a stronger on-line expression of the $\mathrm{CB}$ for companies operating in the B2B context impacts favorably in the financial performance of the company.

\subsection{Managerial implications}

The study has relevant managerial implications, in particular, considering the relevance of CB as an instrument for business differentiation amongst audiences in the marketplace and within the overall business environment. The findings suggest that developing a strong online expression of the $\mathrm{CB}$ is relevant for companies operating in the $\mathrm{B} 2 \mathrm{~B}$ context. The reach of the corporate website is wide, allowing for real-time presentation of the CB.

The study further highlights the role of the company's website in portraying the various features of the $\mathrm{CB}$. As referred earlier, the company's website is a core platform in presenting 
comprehensive information about the company and its offers in the marketplace. When developing their websites managers should also consider the different brand features and the way they are conveyed. In particular, companies aiming to express their CBs through their websites should focus on presenting features that entail the $\mathrm{CB}$ values, personality, citizenship/sustainability, and demographics. The combination of all these features forms a consistent way to show and present the brand in the website.

Managers should also consider the strength of the presence of each CB feature in the website by clearly specifying its scope and reach. For example, companies with history and heritage should capitalize on their tradition in order to create a positive association with the $\mathrm{CB}$. The clear articulation of the company values and mission in the $\mathrm{CB}$ is also relevant. Such feature is important for external and internal stakeholders. Therefore, a clear espousal of the CB values would send a consistent message about the company to all stakeholders. The company's corporate citizenship and involvement in sustainability and societal welfarerelated issues should also be present as a salient feature in the website. Such trait conveys the wider role and impact that the company has in the society in general. Finally, factual details about the company demographics on the website can instill confidence amongst its stakeholders, raising the profile of the CB.

In addition, managers should be aware of the impact that the way the $\mathrm{CB}$ is presented online may have on their financial performance. The results indicate that the reach of the expression of the $\mathrm{CB}$ has impact over the way the brand will be interpreted and, ultimately, may affect financial performance. Such aspect aligns with the idea that having a well-defined corporate position is a source of competitive advantage and contributes to higher performance.

\subsection{Limitations and future research}

Our findings are contingent on some limitations which we also identify as potential areas for future research. Constructs' measurement and validation are an on-going process. In this study we considered a number of variables pertaining to online $\mathrm{CB}$ expressions. Future studies may enlarge the dimensions, and consider other traits of the $\mathrm{CB}$, such as, the corporate name and symbols and how they are used in the brand hierarchy. We also recommend further research comparing the $\mathrm{CB}$ dimensions of companies in emerging markets with those of the companies in developed economies. Additionally, our study did not include primary data, 
therefore, future investigations may survey the perceptions of the $\mathrm{B} 2 \mathrm{~B}$ managers on the $\mathrm{CB}$ dimensions, which will give insights into how corporate brands are created and managed. In order to assess the effectiveness of the $\mathrm{CB}$ management, studies may measure the perceptions and interpretations of B2B stakeholders (e.g., buyers and investors) regarding the specific CB features.

Our sample of B2B companies included companies that are present in the stock market. A future study can try to capture other groups of companies with different demographics (e.g., size), and examine the impact of $\mathrm{CB}$ on market performance among those groups. This would help understanding how branding at the corporate level could be leveraged by different types of companies (e.g., smaller companies). Moreover, given the plethora of sectors in the B2B domain, it is logical to assume that there are sectorial differences in terms of relevance of the CB features. Examining whether different types of dimensions are relevant for different sectors merits further research in order to gain knowledge on the differential impact of $\mathrm{CB}$ features. 


\section{References}

Aaker, D. (1996) Building Strong Brands. New York: The Free Press.

Aaker, J. (1997). Dimensions of brand personality. Journal of Marketing Research, 34(3), $347-56$.

Aaker, A. D. (2004). Leveraging the Corporate Brand. California Management Review, 46(3), 6-18.

Aaker, D. \& Joachimsthaler, E. (2002). Brand Leadership, New York, Simon \& Schuster.

Abdullah, Z., Nordin, S., \& Aziz, Y. (2013). Building a unique online corporate identity. Marketing Intelligence \& Planning, 31(5), 451-471.

Abratt, R. \& Kleyn, N. (2011). Corporate identity, corporate branding and corporate reputations, reconciliation and integration. European Journal of Marketing, 46(7/8), 1048-1063.

Adams, C. \& Frost, G. (2006). Accessibility and functionality of the corporate web site: implications for sustainable reporting. Business Strategy and the Environment, 15(4), 257-287.

Ashforth, B. \& Mael, F. (1989). Social Identity Theory and the Organisation. Academy of Management Review, 14(1), 20-39.

Aspara, J. \& Tikkanen, H. (2008a). Significance of corporate brand for business-to-business companies. The Marketing Review, 8(1), 43-60.

Aspara, J. \& Tikkanen, H. (2008b). Adoption of corporate branding by managers: Case of a Nordic business-to-business company. Brand Management, 16(1-2), 80-91.

Ballantyne, D. \& Aitken, R. (2007). Branding in B2B markets: insights from the servicedominant logic of marketing. Journal of Business \& Industrial Marketing, 22(6), 363371.

BDO (2012). http://www.bdointernational.com/AmbitionSurvey2012/Documents/Infographic .pdf (Accessed September 2014).

BDO (2014). Available at: http://www.bdointernational.com/AmbitionSurvey2012/Countryresults/Pages/Brazil.aspx (Accessed May 2014). 
Backhaus, K., Steiner, M. \& Lügger, K. (2011). To invest, or not to invest, in brands? Drivers of brand relevance in B2B markets. Industrial Marketing Management, 40(7), 10821092.

Balmer, J.M.T. (2001). Corporate identity, corporate branding and corporate marketing: seeing through the fog. European Journal of Marketing, 35(3-4), 248-91.

Balmer, M. T. (2012). Strategic corporate brand Alignment. Perspectives from identity based views of corporate brands. European Journal of Marketing, 46(7/8), 1064-1092.

Beverland, M., Napoli, J., \& Lindgreen, A. (2007). Industrial global brand leadership: a capabilities view. Industrial Marketing Management, 36(8), 1082-1093.

Biggemann, S., \& Fam, K. S. (2011). Business marketing in BRIC countries. Industrial Marketing Management, 40(1), 5-7.

Blombäck, A. \& Axelsson, B. (2007). The role of corporate brand image in the selection of new subcontractors. Journal of Business \& Industrial Marketing, 22(6), 418-430.

Bloomberg Stock Index. Available at: www.bloomberg.com (Accessed April, 2014).

Booth, N. \& Matic, J.A. (2011). Mapping and leveraging influencers in social media to shape corporate brand perceptions. Corporate Communications: An International Journal, 16(3), 184-191.

BRICS Bank (2014). http://www.washingtonpost.com/blogs/monkey-cage/wp/2014/07/17/ what-the-new-bank-of-brics-is-all-about/ (Accessed September 2014.

Brown, S., Kozinets, R.V. \& Sherry, J.F. Jr (2003). Teaching old brands new tricks: retro branding and the revival of brand meaning. Journal of Marketing, 67(3), 19-33.

Burgess, S. M., \& Steenkamp, J.E.M. (2006). Marketing renaissance: How research in emerging markets advances marketing science and practice. International Journal of Research in Marketing, 23(4), 337-356.

Byrne, B. (2004). Testing for multigroup invariance using amos graphics: a road less traveled. Structural Equation Modeling, 11(2), 272-300.

Carlson, B. D., Suter, T. A., \& Brown, T. A. (2008). Social versus psychological brand community: The role of psychological sense of brand community. Journal of Business Research, 61(4), 284-291. 
Cohen, J., \& Cohen, P. (1983). Applied multiple regression/correlation analysis for the behavioral sciences $\left(2^{\text {nd }}\right.$ Ed.). Hillsdale, NJ: Erlbaum.

Coleman, D., de Chernatony, L. \& Christodoulides, G. (2011). B2B service brand identity: Scale development and validation. Industrial Marketing Management, 40(7), 10631071.

Collins, J. \& Porras, J. (1991). Organisational Vision and Visionary Organisations. California Management Review, Fall, 30-52.

da Silveira, C., Lages, C. \& Simões, C. 2013. Reconceptualizing brand identity in a dynamic environment. Journal of Business Research, 66(1), 28-36.

Davis, D. F., Golicic, S. L., \& Marquardt, A. J. (2008). Branding a B2B service: Does a brand differentiate a logistics service provider? Industrial Marketing Management, $37(2), 218-227$.

Doyle, P. (2000). Value-Based Marketing - Marketing Strategies for Corporate Growth and Shareholder Value. Chichester: John Wiley \& Sons.

Eberl, M. \& Schwaiger, M. (2005). Corporate reputation: disentangling the effects on financial performance. European Journal of Marketing, 39(7/8), 838-854.

Ellwood, I. (2002). The Essential Brand Book, London, Kogan Page Limited.

Esrock, S. \& Leichty, G. (2000). Organization of corporate web pages: Publics and functions. Public Relations Review, 26(3), 327-344.

Fombrun, C.J. \& Shanley, M. (1990). What's in a name? Reputation building and corporate strategy. Academy of Management Journal, 33(2), 233-58.

Fornell, C., \& Larcker, D. (1981). Evaluating structural equation models with unobservable variable and measurement error. Journal of Marketing Research, 18(1): 39-50.

Gray, E. \& Smeltzer, L. (1987). Planning a Face-Lift: Implementing a Corporate Image Program. Journal of Business Strategy, 8(1), 4-10.

Gray, E. and L. Smeltzer. (1985). SMR Forum: Corporate Image - An Integral Part of Strategy. Sloan Management Review, Summer,73-78.

Glynn, M. (2010). The moderating effect of brand strength in manufacturer-reseller relationships. Industrial Marketing Management, 39(8), 1226-1233. 
Gupta, S. \& Kumar, V. (2013). Sustainability as corporate culture of a brand for superior performance. Journal of World Business, 48(3), 311-320.

Gupta, S., Czinkota, M. \& Melewar, T. C. (2013). Embedding knowledge and value of a brand into sustainability for differentiation. Journal of World Business, 48(3), 287296.

Gylling, C. \& Lindberg-Repo, K. (2006). Investigating the links between a corporate brand and a customer brand. Journal of Brand Management, 13(4-5), 257-267.

Hakala, U., Lätti, S. \& Sandberg, B. (2011). Operationalising brand heritage and cultural heritage. Journal of Product \& Brand Management, 20(6), 447-456.

Harvey, S. (1998). A Practical Approach to Stating Your 'Mission'. Executive January, 2-3.

Hatch, M. \& Schultz, M (2003). Bringing the corporation into corporate branding. European Journal of Marketing, 37(7/8), 1041 - 1064.

Herbst, U. \& Merz, M. (2011). The industrial brand personality scale: Building strong business-to-business brands. Industrial Marketing Management, 40(7), 1072-1081.

Ind, N. (1997). The Corporate Brand. London: Macmillan Press.

Ingenhoff, D. \& Fuhrer, T. (2010). Positioning and differentiation by using brand personality attributes: Do mission and vision statements contribute to building a unique corporate identity? Corporate Communications: An International Journal, 15(1), 83-101.

Inskip, I. (2004). Corporate branding for small to medium-sized businesses - a missed opportunity or an indulgence? Journal of Brand Management, 11(5), 358-365.

Kapferer, J.-N. (2008). New Strategic Brand Management: Creating and Sustaining Brand Equity Long Term, London, Kogan Page.

Kapur, M \& Mohan, R. (2014). India’s Recent Macroeconomic Performance: An Assessment and Way Forward. International Monetary Fund Working Paper, Available at: http://www.imf.org/external/pubs/ft/wp/2014/wp1468.pdf (Accessed May 2014).

Kay, M. J. (2006). Strong brands and corporate Brands. European Journal of Marketing, 40(7/8), 742-760.

Keller, K. (2008). Strategic Brand Management, 3rd edn, London, Prentice Hall. 
Keller, K. (2009). Building strong brands in a modern marketing communications environment. Journal of Marketing Communications, 15(2-3), 139-155.

Keller, K. L. \& Richey, K. (2006). The importance of corporate brand personality traits to a successful 21st century business, Brand Management, 14, 1/2, 74-81

Knox, S. \& Bickerton, D. (2003). The six conventions of corporate branding. European Journal of Marketing, 37 (7/8): 998-1016.

Kotler, P. \& Pfoertsch, W. (2007). Being known or being one of many: the need for brand management for business-to-business (B2B) companies. Journal of Business \& Industrial Marketing, 22(6), 357-362.

Kumar, V. \& Christodoulopoulou, A. (2014). Sustainability and branding: An integrated perspective. Industrial Marketing Management, 43(1), 6-15.

Kumar, N. \& Steenkamp, J-B E. M. (2013). Brand breakout: How emerging market brands will go global. Hampshire: Palgrave Mcmillan.

Lassen, L., Kunde, P., \& Gioia, C. (2008). Creating a clearly differentiated SME brand profile: The case of Montana A/S. Journal of Brand Management, 16, 92-104.

Lerner, L. \& G. Fryxell. (1994). CEO Stakeholder Attitudes and Corporate Social Activity in the Fortune 500. Business \& Society 33(1), 58-81.

Lindgreen, A., Beverland, M. B., \& Farrelly, F. (2010). From strategy to tactics: Building, implementing, and managing brand equity in business markets. Industrial Marketing Management, 39(8), 1223-1225.

Lynch, J., \& de Chernatony, L. (2004). The power of emotion: Brand communication in business-to-business markets. Journal of Brand Management, 11(5), 403-419.

MDICE (2011) http://www.desenvolvimento.gov.br/arquivos/dwnl_1312203713.pdf

Michaelidou, N., Siamagka, N. T., \& Christodoulides, G. (2011). Usage, barriers and measurement of social media marketing: An exploratory investigation of small and medium B2B brands, Industrial Marketing Management, 40(7), 1153-1159.

Munoz, T. \& Kumar, S. (2004). Brand metrics: Gauging and linking brands with business performance. Journal of Brand Management, 11(5), 381-387.

Nuryanti, W. (1996). Heritage and postmodern tourism. Annals of Tourism Research, 23(2), 249-60. 
Okazaki, S. (2006). Excitement or sophistication? A preliminary exploration of online brand personality. International Marketing Review, 23(3), 279-303.

Opoku, R., Abratt, R., Bendixen, M., \& Pitt, L. (2007). Communicating brand personality: are the web sites doing the talking for food SMEs? Qualitative Market Research: an International Journal, 10(4), 362-374.

Perreault W. D., \& Leigh, L. E. (1989). Reliability of nominal data based on qualitative judgments. Journal of Marketing Research, 26(2), 135-148.

Persson, N. (2010). An exploratory investigation of the elements of B2B brand image and its relationship to price premium. Industrial Marketing Management, 39(8), 1269-1277.

Planning Commission, Government of India (2014). A Macroeconomic Summary: Available at: http://planningcommission.nic.in/data/datatable/1203/table_1.pdf. (Accessed April, 2014).

Pollach, I. (2005). Corporate self-presentation on the WWW: strategies for enhancing usability, credibility and utility. Corporate Communications: An International Journal, 10(4), 285-301.

Rao, V., Agarwal, M., \& Dahlhoff, D. (2004). How is manifest branding strategy related to the intangible value of a corporation? Journal of Marketing, 68(4), 126-141.

Roberts, J. \& Merrilees, B. (2007). Multiple roles of brands in business-to-business services. Journal of Business \& Industrial Marketing, 22(6), 410-417.

Sheth, J. N. (2011). Impact of Emerging Markets on Marketing: Rethinking Existing Perspectives and Practices. Journal of Marketing, 75(4), 166 -182.

Simms; C. D. \& Trott, P. (2006). The perceptions of the BMW Mini brand: the importance of historical associations and the development of a model. Journal of Product \& Brand Management, 15(4), 228-238.

Simões, C., Dibb, S. and Fisk, R. (2005). Managing Corporate Identity: An Internal Perspective. Journal of the Academy of Marketing Science, 33(2): 153-168.

Topalian, A. (2003). Experienced reality: the development of corporate identity in the digital era. European Journal of Marketing, 37(7/8), 1119-1132. 
Torelli, C.J., Özsomer, A., Carvalho, S.W, Keh, H.T., \& Maehle, N. (2012). Brand concepts as representations of human values: do cultural congruity and compatibility between values matter? Journal of Marketing, 76(4), 92-108.

Uzunoglu, E. \& Kip, S. (2014). Building relationships through websites: A content analysis of Turkish environmental non-profit organizations' (NPO) websites. Public Relations Review, 40(1), 113-115.

Vallaster, C., \& de Chernatony, L. (2006). Internal brand building and structuration: the role of leadership. European Journal of Marketing, 40(7/8), 761-768.

van Riel, A. C. R., de Mortanges, C. P., \& Streukens, S. (2005). Marketing antecedents of industrial brand equity: An empirical investigation, in speciality chemicals. Industrial Marketing Management, 34(8), 841-847.

Webster, F. \& Keller, K. (2004). A roadmap for branding in industrial markets. Journal of Brand Management, 11(5), 388-402.

Wiersema, F. (2013). The B2B Agenda: The current state of B2B marketing and a look ahead. Industrial Marketing Management, 42(4), 470-488.

Wilson, D. \& Purushottam, R. (2003). Dreaming with the BRICS. Goldman Sachs Annual Report. Available at: http://www.goldmansachs.com/our_firm/investor_relations/financial_reports/annual_r eports/2003/features/innovativebrics.html (Accessed August 2014). 


\section{Appendix}

\section{Correlation Matrix for the CB Features}

\begin{tabular}{|c|c|c|c|c|c|c|}
\hline & CB expressions in the website & 1 & 2 & 3 & 4 & 5 \\
\hline \multirow{5}{*}{ 定 } & 1. CB values & - & & & & \\
\hline & 2. Citizenship/Corporate sustainability &, $332 * *$ & - & & & \\
\hline & 3. Company demographics &, $311 * *$ &, $422 * *$ & - & & \\
\hline & 4. Heritage of the $\mathrm{CB}$ &, $402 * *$ &, $319 * *$ &, $323 * *$ & - & \\
\hline & 5. Personality of the CB &, $563 * *$ &, $580 * *$ &, $551 * *$ &, $539 * *$ & - \\
\hline \multirow{5}{*}{ } & 1. $\mathrm{CB}$ values & - & & & & \\
\hline & 2. Citizenship/Corporate sustainability &, $407 * *$ & - & & & \\
\hline & 3. Company demographics &, $371 * *$ &, $505 * *$ & - & & \\
\hline & 4. Heritage of the $\mathrm{CB}$ &, $378 * *$ &, $340 * *$ &, $401 * *$ & - & \\
\hline & 5. Personality of the $\mathrm{CB}$ &, $609 * *$ &, $471 * *$ &, $550 * *$ &, $529 * *$ & - \\
\hline
\end{tabular}

Note: all correlations are significant $(\mathrm{p}<0.01)$. 
Table 1: Description of the website CB features

\begin{tabular}{lll}
\hline \multicolumn{1}{c}{$\begin{array}{c}\text { CB expressions in the } \\
\text { website }\end{array}$} & \multicolumn{1}{c}{ Description } & Sources \\
\hline CB values & $\begin{array}{l}\text { We used as proxy for the CB values the mission and } \\
\text { values of the company. } \\
\text { The website presents the CB mission and/or values. } \\
\text { The level of detail and importance given to this feature. }\end{array}$ & $\begin{array}{l}\text { Aaker, 2004; Hatch \& Schultz, } \\
\text { 2003; Simões, Dibb \& Fisk, 2005 }\end{array}$ \\
\hline CB Personality & $\begin{array}{l}\text { The website reveals the personality for the CB: } \\
\text { performance-oriented, competent, leading, exciting, } \\
\text { charming, sincere, credible, etc... }\end{array}$ & $\begin{array}{l}\text { Adapted from Herbst \& Merz, } \\
\text { 2011; Opoku, Bendixen \& Pitt, } \\
\text { 2007 }\end{array}$ \\
\hline Heritage of the CB & $\begin{array}{l}\text { We used as a proxy for the heritage of corporate brand } \\
\text { the company history and origins. }\end{array}$ & $\begin{array}{l}\text { Aaker, 2004; Brown, Kozinets \& } \\
\text { Sherry, 2003; Hakala, Lätti \& }\end{array}$ \\
& $\begin{array}{l}\text { The website includes the Company History and origin } \\
\text { and its background with stories about their creators and }\end{array}$ & Sandberg, 2011 \\
origins. & \\
\hline $\begin{array}{l}\text { Sustainability in the CB } \\
\text { The website addresses corporate sustainability issues in }\end{array}$ & $\begin{array}{l}\text { Aaker, 2004; Kumar \& } \\
\text { more or less detail }\end{array}$ & \& Kumar, 2013 \\
\hline $\begin{array}{l}\text { Company leadership: } \\
\text { founder and/or top } \\
\text { management }\end{array}$ & $\begin{array}{l}\text { The website identifies and includes information about } \\
\text { the company's leaders: founders and/or top } \\
\text { management }\end{array}$ & Kapferer, 2008; Aaker, 2004 \\
\hline Company demographics & $\begin{array}{l}\text { Existence of information and the level of detail given } \\
\text { regarding the company's geographic origin/location, } \\
\text { number of employees, structure, subsidiaries, industry } \\
\text { (etc.). }\end{array}$ & Persson, 2010 \\
\hline
\end{tabular}


Table 2: Sample profile

\begin{tabular}{lcc}
\hline \multicolumn{1}{c}{ Industry } & Brazilian Sample & Indian Sample \\
\hline Basic Materials & 11 & 19 \\
Communications & 5 & 6 \\
Consumer durables & 22 & 29 \\
Consumer non-durables & 24 & 27 \\
Diversified & 6 & 2 \\
Energy & 4 & 3 \\
Financial & 52 & 23 \\
Funds & 0 & 2 \\
Government & 0 & 1 \\
Industrial & 15 & 34 \\
Technology & 3 & 9 \\
Utilities & 16 & 3 \\
\hline Total Cases & $\mathbf{1 5 8}$ & $\mathbf{1 5 8}$ \\
\hline
\end{tabular}


Table 3: Confirmatory Factor Analysis Results

\begin{tabular}{llc}
\hline \multicolumn{1}{c}{ Construct $^{\mathbf{a}}$} & \multicolumn{1}{c}{ Statement } & Standardized Loading $^{\mathbf{b}}$ \\
\hline CB expressions in the & Company demographics & 0,71 \\
website & Sustainability in the CB & 0,69 \\
& CB values & 0,65 \\
& Heritage of the CB & 0,62 \\
& Personality of the CB & 0,91 \\
\hline Performance & Market capitalization & 0,43 \\
& Net revenue & 0,93 \\
& Total assets & 0,83 \\
${ }^{\mathbf{a}}$ Model fit indexes: $\chi 2=53.994, \mathrm{df}=19, \chi 2 /$ df $=2.842, \mathrm{RMSEA}=0.077, \mathrm{GFI}=0.960, \mathrm{AGFI}=0.923, \mathrm{TLI}=$ \\
0.947, and CFI $=0.964 . ;{ }^{b}$ All loadings were significant $(\mathrm{p}<0.01)$.
\end{tabular}


Table 4: Correlation Matrix and Descriptive Statistics of Measures

\begin{tabular}{lccccccc}
\hline \multicolumn{1}{c}{ Variables } & Mean & S.D. & Alpha & CR & AVE & 1 & 2 \\
\hline 1. Corporate Brand & 2.769 & 1.055 & 0.82 & 0.84 & 0.52 & $\mathbf{0 . 7 2}$ & \\
2. Performance & -0.003 & 0.926 & 0.73 & 0.79 & 0.58 & $0.222^{* *}$ & $\mathbf{0 . 7 6}$ \\
\hline
\end{tabular}

Note: Diagonal elements (in bold) are the square root of the average variance extracted $(\mathrm{AVE}) ; * \mathrm{p}<0.01$. 
Table 5: Mean and standard deviation for $\mathrm{CB}$ features in each country

\begin{tabular}{lcccc}
\hline \multicolumn{1}{c}{ CB expressions in the website } & \multicolumn{2}{c}{ Brazil } & \multicolumn{2}{c}{ India } \\
& Mean & SD & Mean & SD \\
\hline CB values & 2.97 & 1.708 & 2.23 & 1.301 \\
Sustainability in the CB & 3.14 & 1.747 & 1.72 & 1.157 \\
Company demographics & 3.88 & 1.024 & 2.36 & 0.831 \\
Heritage of the CB & 3.06 & 1.504 & 2.33 & 1.000 \\
Personality of the CB & 3.42 & 1.005 & 2.58 & 0.972 \\
\hline
\end{tabular}

Note: The CB features' means are all significantly different between countries. 
Table 6: Correlation Matrix between CB features and performance

\begin{tabular}{l|ccc|c|}
\hline \multicolumn{1}{|c|}{ CB expressions in the website } & $\begin{array}{c}\text { Total } \\
\text { Assets }\end{array}$ & $\begin{array}{c}\text { Market } \\
\text { Cap }\end{array}$ & $\begin{array}{c}\text { Net } \\
\text { Revenue }\end{array}$ & $\begin{array}{c}\text { Overall } \\
\text { Performance }\end{array}$ \\
\hline CB values & .057 & .038 & .044 & .043 \\
Sustainability in the CB & $.174 *$ & $.221 * *$ & $.187 *$ & $.213 * *$ \\
Heritage of the CB & .046 & .043 & .031 & .042 \\
Personality of the CB & $.186^{*}$ & .152 & $.179 *$ & $.168^{*}$ \\
CB values & $.193 *$ & $.194 *$ & $.195 *$ & $.200^{*}$ \\
\hline Sustainability in the CB & .116 & .003 & .154 & .132 \\
Company demographics & $.311^{* *}$ & $.411^{* *}$ & $.427 * *$ & $.393 * *$ \\
Heritage of the CB & $.252 * *$ & $.302 * *$ & $.385 * *$ & $.331 * *$ \\
Personality of the CB & $.187 *$ & .067 & $.243 * *$ & $.214 * *$ \\
\hline
\end{tabular}

${ }^{\mathbf{a}}$ The overall Performance measure = mean (Total Assets, Market Cap, and Net Revenue Z-scores). $* \mathrm{p}<0.05 ; * * \mathrm{p}<0.01$ 
Figure 1: Impact of CB features in Performance

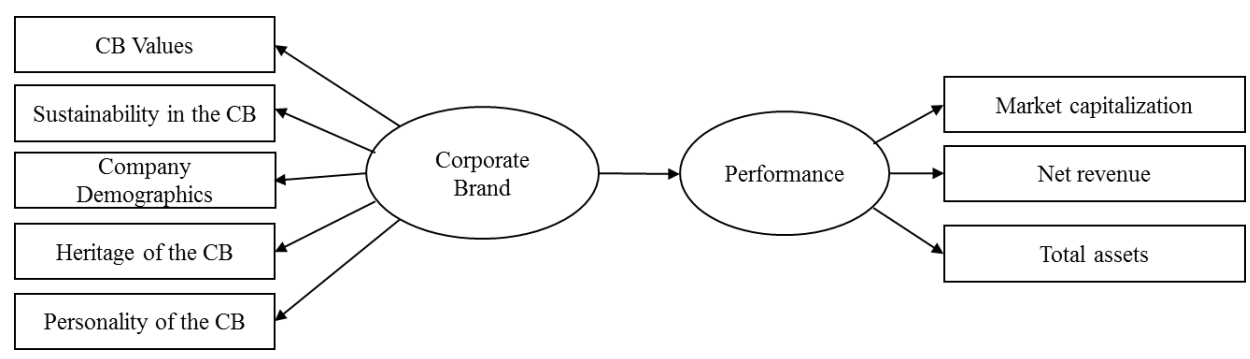

